\title{
D VITAMINO IR DEPRESIJOS RYŠYS
}

\author{
Adas Gudaitis, Karolina Prielaidaitè \\ Lietuvos sveikatos moksly universitetas, Medicinos fakultetas
}

Raktažodžiai: D vitaminas, depresija.

\section{Santrauka}

Depresija yra vienas iš dažniausių psichiatrinių susirgimų, pasitaikančių žmonių populiacijoje, stipriai paveikiantis gyvenimo kokybę ir darbingumą. Depresijos ligos etiologija yra sudètinga, galutinai neišaiškinta, turinti daugybę patogenezinių mechanizmų.. Pastaraisiais metais vis daugiau kalbama apie D vitamino trūkumo įtaką depresijos vystymuisi. Tyrimo tikslas - apžvelgti D vitamino reikšmę žmogaus organizmui ir išsiaiškinti, kaip jo trūkumas susijęs su depresijos ligos atsiradimu. Literatūros šaltinių paieška atlikta kompiuterinèse bibliografinèse mokslinių darbų bazèse PubMed ir Google Scholar, naudojant raktažodžius ir jų derinius. Analizei atrinkti ir išnalizuoti 23 moksliniai straipsniai anglų kalba, atitinkantys tyrimo temą. Tyrimo rezultatai atskleide, kad dvidešimtojo amžiaus devintajame dešimtmetyje buvo padaryta reikšmingų neurobiologijos tyrimų, sakančių, jog D vitamino receptoriu gausu CNS dalyse, glaudžiai susijusiose su depresijos patogeneze. D vitaminas riebaluose tirpus, ji žmogaus organizmas gali gauti trimis būdais: būnant apšviestam saulès, valgant specifini maistą ir geriant $\mathrm{D}$ vitaminą, kaip maisto papildą. Išvados: 1) vitamino $D$ trūkumas gali būti vienas iš depresijos rizikos veiksnių; 2) patvirtinta koreliacija tarp mažos 25(OH)D koncentracijos ir padidejjusios depresijos rizikos bei jos simptomų atsiradimo; 3) normalaus D vitamino lygio kraujyje palaikymas gali padèti išvengti depresijos.

\section{Ivadas}

Depresijos epizodas Tarptautinès ligų klasifikacijos 10 leidime (TLK-10-AM) koduojamas F32. Jam būdinga liūdna nuotaika, sumažèjusi energija ir aktyvumas. Dažnai pasireiškia sumažèjęs pasitenkinimas, interesų ratas, dèmesio koncentracija ir didelis nuovargis net ir nuo minimalių pastangų. Beveik visada sumažeja saviverte ir pasitikejjimas savimi, o kaltès ir nevisavertiškumo idejos būdingos net ir lengvos depresijos epizodui. Didžiausias depresijos pasireiškimas ryte, stiprus psichomotorinis slopinimas, susijaudinimas (ažitacija), apetito praradimas, svorio netekimas ir libido susilpnejimas [1]. $2001 \mathrm{~m}$. duomenimis, depresijos paplitimas Europoje buvo 8,5 proc., stebint didesnị paplitimą šiaurinèse ir mažesni - pietinėse Europos šalyse [2]. Pasaulio sveikatos organizacija yra pareiškusi, jog prie šio skaičiaus pridejjus nerimo ar lengvos depresijos paplitimo skaičius, gautume 25 proc. paplitimą Europoje [3]. Depresiją sukeliančių veiksnių yra daug, tačiau pastaraisiais metais vis daugiau kalbama apie nepakankamos mitybos ir vitaminų trūkumo, konkrečiai D vitamino įtaką depresijos vystymuisi [4].

Tyrimo tikslas - apžvelgti D vitamino reikšmę žmogaus organizmui ir išsiaiškinti, kaip jo trūkumas susijęs su depresijos ligos atsiradimu.

\section{Tyrimo medžiaga ir metodai}

Atlikta literatūros šaltinių paieška kompiuterinèse bibliografinèse mokslinių darbų bazėse PubMed ir Google Scholar, naudojant raktinius žodžius ir jų derinius: vitamine $\mathrm{D}$, depression. Analizuoti moksliniai straipsniai anglų kalba, atitinkantys tyrimo temą.

\section{Tyrimo rezultatai}

D vitaminas ir jo samprata. $D$ vitaminas tirpus riebaluose. Žmogaus organizmas gali gauti D vitamino 3 būdais: būnant apšviestam saulès, valgant specifinį maistą ir geriant D vitaminą kaip maisto papildą [5]. Yra du šio vitamino prekursoriai, kuriuos gali pasisavinti žmogaus organizmas: D3 vitaminas (cholekalciferolis), gaunamas iš gyvūninès kilmès maisto produktų (šviežia žuvis, skumbrè, ungurys, rūkyta lašiša) ir D2 vitaminas (ergokalciferolis), gaunamas iš augalinès kilmès maisto produktų (grybai, sojos pienas). Nors D3 vitaminas žmogaus organizmui duoda 3 kartus didesnị atsaką, nei D2, tačiau mitybos neužtenka palaikyti normalų D vit. kiekị žmogaus organizme, net ir suvartojant daug gyvūninès kilmès maisto [6]. Pagrindinis D vit. šaltinis yra saulès šviesa. Mokslineje literatūroje teigiama, jog palaikyti normalų $\mathrm{D}$ vitamino paros lygį užtenka vidurdienį pabūti saulèje 12 minučių, nepasitepus kremu nuo saulès [7]. Saulès šviesos konvertavimas ị D vit. yra sudètingas bioche- 
minis procesas, kurio produktas yra aktyvioji $\mathrm{D}$ vit. forma - 25(OH)D. Skaičiuojama, kad 12 minučių saulès apšvietos metu susidaro tiek pat D vitamino, kiek geriant apie 3000UI D vitamino maisto papildo [7]. Ši informacija tik patvirtina, kodèl stebimas ryškus D vitamino lygio skirtumas, lyginant žiemos ir vasaros sezonus $[8,9]$.

D vitamino neurobiologija. Dvidešimtojo amžiaus devintajame dešimtmetyje, kai cerebrospinaliniame skystyje buvo atrasti $\mathrm{D}$ vit. metabolitai, buvo patvirtinta, jog D vitaminas glaudžiai susijęs su neurobiologija ir dalyvauja smegenų vystymesi [10]. Nors D vitaminas turi receptorių beveik visuose audiniuose ir ląstelèse, jis yra laikomas neurosteroidu, kadangi jo specifiškų receptorių randama smegenų dalyse: prefrontalinèje žieveje (lot. Cortex praefrontalis), hipotalame (Hypothalamus), gumbure (Thalamus), hipokampe (Hippocampus), juodojoje medžiagoje (Substantia nigra), juostinejje raukšlejje (Cingulate gyrus) [11,12]. Šios dalys yra glaudžiai susijusios su depresijos liga ir dažnai būna pažeistos ja sergant [13]. Atlikus tyrimą su pelèmis, kurioms buvo maitintas metamfetaminas, vitaminas D padèjo atkurti ženkliai nukritusius dopamino lygius dryžuotajame kūne (lot. corpus striatum) ir pasvirajame branduolyje (lot. nucleus accumbens) [14].

D vitamino veikimo mechanizmas depresijos kontekste. Viena iš pagrindinių $\mathrm{D}$ vitamino funkcijų yra palaikyti ląstelių, šiame kontekste, neuronų kalcio jonų ir laisvujų radikalų homeostazę $[15,16]$. D vitaminas mažina L tipo CaV1.2 ir CaV1.3 kanalų hipokampe [17] ir žieviniuose neuronuose ekspresiją [18]. Tai reiškia, kad esant D vitamino trūkumui, šie kanalai aktyvuojami, didejja viduląstelinis kalcio jonų kiekis neuronuose, stebimas sergant depresija.

Kita svarbi D vitamino funkcija yra kontroliuoti serotonino gamybą. Serotoninas yra neuromediatorius, glaudžiai susijęs su depresijos liga [19]. Tyrimai rodo, kad D vitaminas skatina serotonino sintezavimo geną, kurio déka pagaminama triptofano hidroksilazė 2. Tai yra serotonino pirmtakas [20]. Tai rodo, kad D vit. gali padèti palaikyti normalų serotonino lygị ir išvengti depresinès simptomatikos.

Naujausi tyrimai rodo, jog D vitamino metabolitai netiesiogiai skatina neromediatorių dopamino ir noradrenalino sintezę, darydami ịtaką tirozino hidroksilazès genų ekspresijai [11]. Tirozino hidroksilaze yra dopamino ir norepinefrino pirmtakas. Šie neuromediatoriai yra itin svarbūs depresijos kontekste [19].

Viena iš svarbiausių D vitamino funkcijų yra DNR demetilazès ekspresijos reguliavimas [21]. DNR demetilazė stabdo demielinizaciją, trukdydama genams sintezuoti baltymus, kurie pradeda demielinizacijos pocesą. Depresijos kontekste, demielinizacijos procesas labiausiai stebimas GABAerginiuose neuronuose, kurių dydžio ir skaičiaus ma- žèjimas neuroanatominèse struktūrose skatina depresijos vystymąsi [22,23].

\section{Išvados}

1. Remiantis moksliniais tyrimais, veikimo mechanizmais, bei depresijos etiologija, D vitamino trūkumas gali būti vienas iš modifikuojamų veiksnių, skatinančių depresijos atsiradimą.

2. D vitamino trūkumo ir depresijos ryšys yra silpnas, tačiau patvirtinta koreliacija tarp mažos $25(\mathrm{OH}) \mathrm{D}$ koncentracijos ir padidejusios depresijos rizikos bei jos simptomų atsiradimo.

3. Normalaus D vitamino lygio kraujyje palaikymas tokiomis priemonèmis kaip subalansuota mityba, maisto papildai ar pakankama saulès apšvieta, padeda išvengti depresijos, o ja sergant tai galima naudoti kaip papildomą gydymo priemonę.

\section{Literatūra}

1. World Health Organisation. The ICD-10 Classification of mental and behavioural disorders. World Health Organization 1992; 55:35-9.

2. Page H, Ayuso-Mateos J, Dowrick C, Vazquez-Barquero J. Depressive disorders in Europe: morbidity figures from the ODIN study. Br J Psychiatry 2001; 179:308-16.

https://doi.org/10.1192/bjp.179.4.308

3. World Health Organizazion. Depression in Europe. World Health Organisation. 2012. http://www.euro.who.int/en/health-topics/noncommunicable-diseases/mental-health/news/ news/2012/10/depression-in-europe

4. Soundy A. Psycho-emotional content of illness narrative master plots for people with chronic illness: implications for assessment. J World J Psychiatry P 2018;8(3).

https://doi.org/10.5498/wjp.v8.i3.79

5. de Boer IH. Vitamin D deficiency. Chronic Kidney Dis Dial Transplant 2010;115-27. https://doi.org/10.1016/B978-1-4377-0987-2.00009-1

6. Maxwell JD. Seasonal variation in vitamin D. Proc Nutr Soc 1994;53(3):533-43.

https://doi.org/10.1079/PNS19940063

7. Holick MF. Vitamin D: a millenium perspective. J Cell Biochem 2003;88(2):296-307.

https://doi.org/10.1002/jcb.10338

8. González-Parra E, Avila PJ, Mahillo-Fernández I, Lentisco C, Gracia C, Egido J, et al. High prevalence of winter 25-hydroxyvitamin D deficiency despite supplementation according to guidelines for hemodialysis patients. Clin Exp Nephrol 2012;16(6):945-51.

https://doi.org/10.1007/s10157-012-0642-2

9. Bird ML, Hill KD, Robertson IK, Ball MJ, Pittaway J, Williams AD. Serum $[25(\mathrm{OH}) \mathrm{D}]$ status, ankle strength and activity show 
seasonal variation in older adults: relevance for winter falls in higher latitudes. Age Ageing 2013;42(2):181-5.

https://doi.org/10.1093/ageing/afs067

10. Balabanova S, Richter HP, Antoniadis G, Homoki J, Kremmer $\mathrm{N}$, Hanle J, et al. Klinische schrift 25-Hydroxyvitamin D , 24 , 25-Dihydroxyvitamin D and 1, 25-Dihydroxyvitamin D in human cerebrospinal fluid. Klin Wochenschr 1984;62(22):108690.

https://doi.org/10.1007/BF01711378

11. Bertone-Johnson ER. Vitamin D and the occurrence of depression: Causal association or circumstantial evidence? Nutr Rev 2009;67(8):481-92.

https://doi.org/10.1111/j.1753-4887.2009.00220.x

12. Eyles DW, Burne THJ, McGrath JJ. Vitamin D, effects on brain development, adult brain function and the links between low levels of vitamin D and neuropsychiatric disease. Front Neuroendocrinol 2013;34(1):47-64.

https://doi.org/10.1016/j.yfrne.2012.07.001

13. Drevets WC, Price JL, Furey ML. Brain structural and functional abnormalities in mood disorders: implications for neurocircuitry models of depression. Brain Struct Funct 2008;213(1-2):93-118.

https://doi.org/10.1007/s00429-008-0189-x

14. Cass WA, Smith MP, Peters LE. Calcitriol protects against the dopamine- and serotonin-depleting effects of neurotoxic doses of methamphetamine. Ann N Y Acad Sci 2006;1074:261-71. https://doi.org/10.1196/annals.1369.023

15. Berridge MJ. Vitamin D: a custodian of cell signalling stability in health and disease. Biochem Soc Trans 2015;43(3):349-358. https://doi.org/10.1042/BST20140279

16. Berridge MJ. Vitamin D cell signalling in health and disease. Biochem Biophys Res Commun 2015;(460):53-71. https://doi.org/10.1016/j.bbrc.2015.01.008

17. Brewer LD, Thibault V, Chen KC, Langub MC, Landfield PW, Porter NM. Vitamin D hormone confers neuroprotection in parallel with downregulation of L-type calcium channel expression in hippocampal neurons. J Neurosci 2001;21(1):98-108. https://doi.org/10.1523/JNEUROSCI.21-01-00098.2001

18. Gezen-Ak D, Dursun E, Yilmazer S. The effects of vitamin $\mathrm{D}$ receptor silencing on the expression of LVSCC-A1C and LVSCC-A1D and the release of NGF in cortical neurons. PLoS One 2011;6(3). https://doi.org/10.1371/journal.pone.0017553
19. Nutt DJ. Relationship of neurotransmitters tothe symptoms of major depressive disorder. J Clin Psychiatry 2008;(69):4.

20. Patrick RP, Ames BN. Vitamin D and the omega-3 fatty acids control serotonin synthesis and action, part 2: relevance for ADHD, bipolar disorder, schizophrenia, and impulsive behavior. FASEB J 2015;29(6):2207-22.

https://doi.org/10.1096/fj.14-268342

21. Pereira F, Barbáchano A, Singh PK, Campbell MJ, Muñoz A, Larriba MJ. Vitamin D has wide regulatory effects on histone demethylase genes. Cell Cycle 2012;11(6):1081-9. https://doi.org/10.4161/cc.11.6.19508

22. Fogaça MV, Duman RS. Cortical GABAergic dysfunction in stress and depression: new insights for therapeutic interventions. Front Cell Neurosci 2019;13:1-20.

https://doi.org/10.3389/fncel.2019.00087

23. Duman RS, Sanacora G, Krystal JH. Altered connectivity in depression: GABA and glutamate neurotransmitter deficits and reversal by novel treatments. Neuron 2019;102(1):75-90. https://doi.org/10.1016/j.neuron.2019.03.013

\section{A LINK BETWEEN VITAMIN D AND DEPRESSION}

\section{A. Gudaitis, K. Prielaidaitė}

Keywords: vitamin D, depression.

Summary

Depression is one of the most common psychiatric illnesses in the human population, with a huge impact on quality of life and work capacity. The etiology of depression is complex, with many pathogenic mechanisms, but it is still not fully understood. In recent years, there has been increasing talk about the impact of vitamin $\mathrm{D}$ deficiency and the development of depression. The purpose of this article is to review vitamin D's role in the human body and how its deficiency is related to the onset of depressive illness. Vitamin D is a fat-soluble vitamin that the human body can get in three ways: by being exposed to the sun, by eating specific foods, and by taking vitamin D as a dietary supplement. As early as the 1980s, significant research was conducted in the field of neurobiology, saying that vitamin D receptors are abundant in parts of the CNS closely related to the pathogenesis of depression.

Correspondence to: adas.gudaitis@gmail.com

Gauta 2021-05-18 